\title{
Ten Niche Strategies To Commercialize New High-Tech Products
}

\author{
J. Roland Ortt ${ }^{1}$, David J. Langley ${ }^{2}$, Nico Pals ${ }^{2}$ \\ ${ }^{l}$ Delft University of Technology, Netherlands, j.r.ortt@tudelft.nl \\ ${ }^{2}$ TNO, Netherlands Organisation for Applied Scientific Research, Netherlands, david.langley@tno.nl, \\ nico.pals@tno.nl
}

\begin{abstract}
There are serious gaps in the scientific literature relating to niche strategies as a means for commercializing new high-tech products. In particular, there is no clarity about what types of niche strategies can be distinguished, or how a niche strategy can be selected to suit a certain situation. In this paper, we identify generic actors, factors and functions that play a role in the commercialization of high-tech products, and that can form barriers to large-scale diffusion, thereby necessitating the implementation of a niche strategy. We analyse thirty-six different market situations and assess historical cases to identify the niche strategies that emerged. We find ten generic niche strategies, each of which can be applied in a number of situations. We present a model to aid managers in purposefully selecting an appropriate niche strategy.
\end{abstract}

\section{Keywords}

Innovation systems, high-tech, large-scale diffusion, barriers, niche strategies

\section{Introduction}

In the late 19th century, telephony was first used as a local burglar alarm in a bank, for intracompany communications and as a means to contact the nearby telegraph office and transfer telegrams [Dordick, 1990] [Huurdeman, 2003] [Winston, 1998]. These niche applications differed fundamentally from the large-scale telephone application that emerged later. Similar differences can be found for other products as well. From the late 1920s on, the contraceptive pill was first introduced as a hormone preparation for complaints such as problem pregnancies, gynaecological cancers, menopausal complaints of women and hormonal disorders in men, before it became a regular contraceptive that diffused in a mass market from the 1960s [Junod and Marks, 2002]. The microwave oven was first used to prepare food in trains and ships from 1947, before it became a standard cooking device in consumer households [Osepchuk, 1984] [Osepchuk, 2009]. These cases have in common that they describe radically new high-tech products (at the time of their introduction) and that different niche applications preceded the large-scale diffusion of these product in a mass-market application.

In the scientific literature, niche strategies are often described as an important step in commercializing new high-tech products [DeBresson, 1995] [Gerlagh et al., 2004] [Hultink et al., 1997] [Lynn et al., 1996] [Meldrum, 1995] [Moore, 2002]. However, when it comes to answering the questions why these niche strategies are important, what types of niche strategies can be distinguished and how a particular niche strategy can be selected, the literature shows serious gaps. A first explanation is provided by [Debruyne et al., 2002] indicating that competitors fail to respond to niche market introductions for radical innovations. The competitive advantages of a niche strategy represents only a partial explanation for the emergence of niche applications, in many cases of niche applications for new high-tech products, no (direct) competitors were active. [Kemp et al, 1998] provide another explanation for the 
emergence of niche applications when they describe a list of barriers preventing large-scale diffusion. These barriers are important but the link between these barriers and particular niche strategies is insufficiently explained.

In this paper we address the following research questions: (1) Why are niche strategies important to commercialize new high-tech products? (2) What are specific niche strategies to commercialize new high-tech products? (3) When are these strategies applicable?

In section 2 we describe the relevant theory. We start by defining the pattern of development and diffusion to indicate the difference between early niches and mature niches. Since the focus is on early niches, we summarize earlier findings regarding these early niches (section 2.1). Then we proceed by comparing different innovation system models indicating the actors, factors and functions (further referred to as factors) required for large-scale development and diffusion of high-tech products. These factors are combined in one overarching model (section 2.2). In section 3 we use this model to illustrate how an assessment of the market situation can help in choosing a particular niche strategy. We illustrate these niche strategies using historical casestudies. In section 4 we answer the research questions, discuss the managerial and scientific relevance of these findings, describe possible limitations and derive future research plans.

\section{Theoretical notions}

\subsection{Niches during the technology life cycle}

A niche application refers to a relatively small group of customers with specific wants and demands regarding a product [Dalgic and Leeuw, 1994] [Shani and Chalasani, 1993]. Parrish, Cassill \& Oxenham [Parrish, Cassill \& Oxenham, 2006] contrast niche and mass marketing in terms of the size of the market (small or large) and product characteristics (specialized or generic functionalities).

Different life cycle models are distinguished in the literature. Rogers [Rogers, 2003] describes a model in which the diffusion of a product (category) follows a smooth S-shaped pattern. This model assumes that the product remains essentially invariant over the life cycle. Or, to put it differently, there is no (product) development parallel to the diffusion process in his model. That may have been true for the first case, a hybrid corn, for which the diffusion model was originally developed, but we think that this model is a special case of a more generic model that holds for new high-tech products. Utterback and Abernathy [Utterback and Abernathy, 1975], using their experiences in the automotive industry, describe that during the diffusion process, innovations do actually appear. They found that radical product innovations primarily appear early on whereas process innovations and more incremental product innovations appear primarily during the later stages of the life cycle. In contrast with Roger's ideas, these authors assume that the product can change during the life cycle. Building on these ideas, different types of innovation (incremental and radical) were distinguished and the life cycle diffusion pattern was adapted accordingly [Abernathy and Utterback, 1978] [Tushman and Anderson, 1986] [Tushman and Rosenkopf, 1992] [Tushman et al., 1997]. Using these notions, Ortt and Schoormans [Ortt and Schoormans, 2004] proposed a model distinguishing three phases in the development and diffusion process: innovation, adaptation and stabilization phase (Figure 1). 


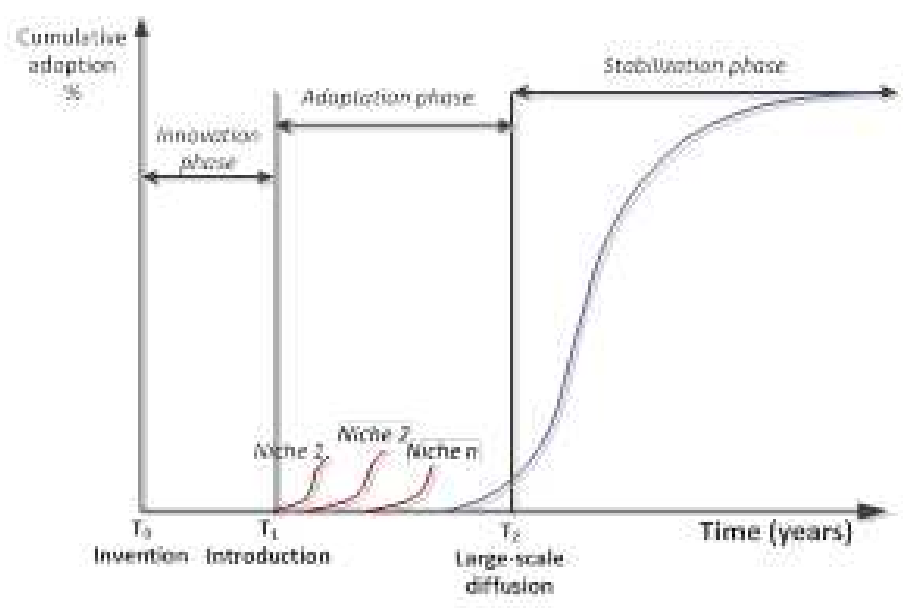

(a) niches prior to large-scale application

Figure 1: A life-cycle model of radically new high-tech products showing early niches prior to large-scale diffusion (adapted from [Ortt and Schoormans, 2004])

In this article the focus is on the adaptation phase, which begins after the first application and ends when a standard product is produced in an industrial production process and large-scale diffusion starts. We define an "early niche" as a niche application that emerges in the adaptation phase i.e., prior to industrial production and large-scale diffusion of a new high-tech product in a mainstream application. A typical early niche is the use of digital imaging in satellites for military surveying. This early niche appeared prior to the use of digital imaging in ordinary photo cameras. Niches can also emerge later on i.e., during large-scale diffusion of a high-tech product, when the market has matured. In the latter case we refer to these niches as "mature niches". An example is the segment of consumers that nowadays want a hand-made and unique car. The adaptation phase lasts on average about 7 years [Ortt, 2011], and many companies enter and leave the market during this phase [Ortt, Shah \& Zegveld, 2007]. In about $80 \%$ of new hightech products, niche applications emerge prior to large-scale diffusion [Ortt, Trevino Barbosa \& Meijer, 2012]. In these cases about two niche applications emerge on average, although this number depends on the industry involved [Ortt \& Suprapto, 2011].

\subsection{Actors, factors or functions required for large-scale diffusion}

Ortt \& Suprapto [Ortt \& Suprapto, 2011] show that different numbers and types of early niches appear per industry. This result is a first step in explaining the emergence of these niches. A second step, addressed in this paper, is to distinguish the specific actors, factors and functions (further referred to as factors) in the industry that play a role in the formation of these niches. Each of the industries represents a different configuration of factors that seems to influence the emergence of early niches. To explore whether and how this configuration causes niches, we adopt the following assumption: Early niches appear when development, production or largescale diffusion and use of a new high-tech product is hampered. Following this line of reasoning, we look at factors in the market required for the development and large-scale diffusion of a new high-tech product.

To find the factors required for the development of new high-tech products we look at factors in complete innovation systems and we combine the information from four descriptions of innovation systems [Bergek et al., 2008] [Edquist, 2011] [Geels, 2004] [Malerba, 2002]. To find factors required for the large-scale diffusion of new high-tech products we use factors that we found earlier in a multi-case study approach on early niches [Ortt \& Suprapto, 2011] and factors 


\section{4-26 June 2013, the Hague}

that were found to influence the length of the adaptation phase [Ortt \& Delgoshaie, 2008]. All of the resulting factors are ordered and combined into twelve categories (see Table 1).

\begin{tabular}{|c|c|}
\hline Factors & Description \\
\hline $\begin{array}{l}\text { New high-tech } \\
\text { product }\end{array}$ & $\begin{array}{l}\text { The product can be defined and distinguished using three elements: the functionality provided by } \\
\text { the product, the technological principle(s) used and the main components in the system (first tier } \\
\text { of subsystems). The unavailability of (one or more components of) the product means that large- } \\
\text { scale diffusion is not (yet) possible. The product needs to have a good price/quality compared to } \\
\text { competitive products in the perception of customers before large-scale diffusion is possible. }\end{array}$ \\
\hline $\begin{array}{l}\text { Production } \\
\text { system }\end{array}$ & $\begin{array}{l}\text { Availability of a good production system is required for large-scale diffusion. In some cases a } \\
\text { product can be created in small numbers as a kind of craftsmanship but industrial production } \\
\text { technologies are not yet available. In that case large-scale diffusion is not possible. }\end{array}$ \\
\hline $\begin{array}{l}\text { Complementary } \\
\text { products and } \\
\text { services }\end{array}$ & $\begin{array}{l}\text { Complementary products and services refer to products and services required for the production, } \\
\text { distribution, adoption and use. The product together with complementary products and services } \\
\text { forms a socio-technological system. The unavailability of elements in that system means that } \\
\text { large-scale diffusion is not (yet) possible. }\end{array}$ \\
\hline $\begin{array}{l}\text { Suppliers } \\
\text { (network of } \\
\text { organizations) }\end{array}$ & $\begin{array}{l}\text { The producers and suppliers refer to the actors involved in the supply of the product. Sometimes } \\
\text { multiple types of actors are required to supply the entire system. In that case a kind of } \\
\text { coordination (network) is required. Sometimes actors with considerable resources are required, for } \\
\text { example to provide an infrastructure. If one or more vital roles, resources or types of coordination } \\
\text { are not present in the socio-technological system, large-scale diffusion is blocked. }\end{array}$ \\
\hline Customers & $\begin{array}{l}\text { The availability of customers means that a market application for the product is identified, that } \\
\text { customer segments for these applications exist and that the customers are knowledgeable about } \\
\text { the product and its use and are willing and able to pay for adoption. If applications are unknown or } \\
\text { if customer groups do not exist, are not able to obtain the product or are unaware of the benefits of } \\
\text { the product, large-scale diffusion is blocked. }\end{array}$ \\
\hline $\begin{array}{l}\text { Institutional } \\
\text { aspects (laws, } \\
\text { rules and } \\
\text { standards) }\end{array}$ & $\begin{array}{l}\text { The regulatory and institutional environment refers to the laws and regulations that indicate how } \\
\text { actors (on the supply and demand side of the market) deal with the socio-technological system. } \\
\text { These laws and regulations can either stimulate the application of radically new high-tech } \\
\text { products (such as subsidy that stimulates the use of sustainable energy) or completely block it } \\
\text { (such as laws prohibiting something). }\end{array}$ \\
\hline $\begin{array}{l}\text { Knowledge of } \\
\text { technology }\end{array}$ & $\begin{array}{l}\text { The knowledge of the technology refers to the knowledge required to develop, produce, replicate } \\
\text { and control the technological principles in a product. In many cases a lack of knowledge blocks } \\
\text { large-scale diffusion. }\end{array}$ \\
\hline $\begin{array}{l}\text { Natural } \\
\text { resources and } \\
\text { labour }\end{array}$ & $\begin{array}{l}\text { Natural resources and labour are required to produce and use a new high-tech product. These } \\
\text { resources and labour can be required for the production system, for complementary products and } \\
\text { services or for the product itself. In many cases a lack of resources and labour block large-scale } \\
\text { diffusion. }\end{array}$ \\
\hline $\begin{array}{l}\text { Knowledge of } \\
\text { application }\end{array}$ & $\begin{array}{l}\text { Knowledge of the application can refer to knowing potential applications. If a technological } \\
\text { principle is demonstrated but there is no clue about its practical application, large-scale diffusion } \\
\text { is impossible. A lack of knowledge of the application can also refer to customers that do not know } \\
\text { how to use a new product in a particular application. In that case large-scale diffusion is not } \\
\text { possible. }\end{array}$ \\
\hline $\begin{array}{l}\text { Socio-cultural } \\
\text { aspects }\end{array}$ & $\begin{array}{l}\text { Socio-cultural aspects refer to the norms and values in a particular culture. These aspects might be } \\
\text { less formalized than the laws and rules in the institutional aspects but their effect might } \\
\text { completely block large-scale diffusion. }\end{array}$ \\
\hline $\begin{array}{l}\text { Macro- } \\
\text { Economic } \\
\text { aspects }\end{array}$ & $\begin{array}{l}\text { Macro-Economic aspects refer to the economic situation. A recession can stifle the diffusion of a } \\
\text { new high-tech product. }\end{array}$ \\
\hline $\begin{array}{l}\text { Accidents or } \\
\text { events }\end{array}$ & $\begin{array}{l}\text { Accidents or events such as wars, accidents in production, accidents in the use of products can } \\
\text { have a devastating effect on the diffusion of a new high-tech product. }\end{array}$ \\
\hline
\end{tabular}

Table 1: Actors, factors and functions necessary for large-scale diffusion. 
The first 6 of the factors described in Table 1 have a direct effect on the large scale diffusion of the high-tech product whereas the last 6 have an indirect effect, because they are a prerequisite for one or more of the first factors. If one or more of the factors are missing, or otherwise forms a barrier to large-scale diffusion, then a niche strategy is required (see Figure 2).

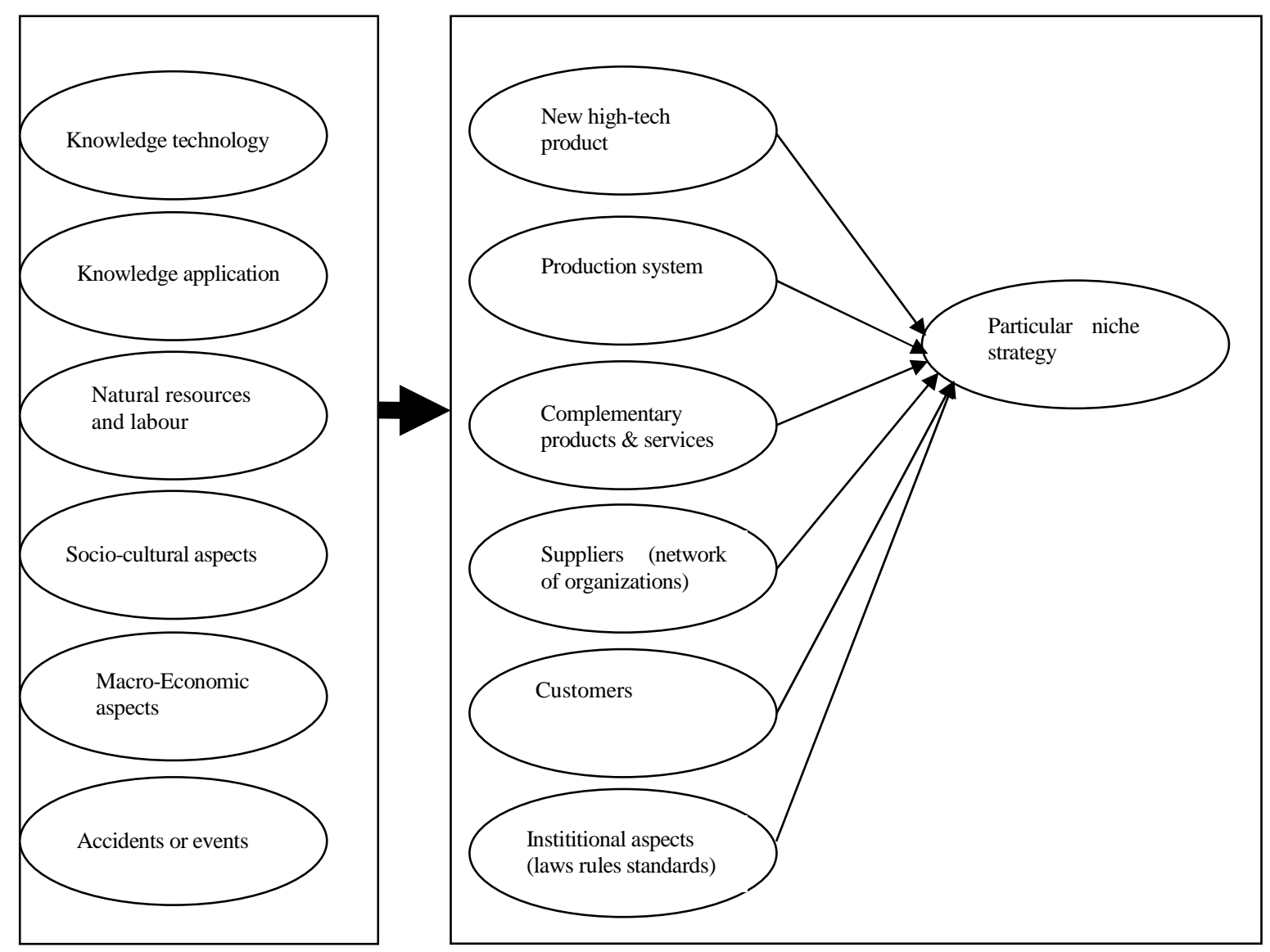

Figure 2: Factors important for the development and large-scale diffusion of new high-tech products

The model in Figure 2 is built up in two layers. The first layer of six factors (right part of Figure 2), referred to as core factors, represents the core technological and market system that is required for large-scale diffusion. Some of these core factors refer to technical components and subsystems such as the product itself, the production system and complementary product and services. Some other factors refer to actors such as suppliers and customers. The institutional aspects refer to the laws, rules, norms and values used to guide processes such as production, supply, adoption and use. Each of these core factors needs to be in place in order to enable largescale diffusion to occur. When one or more hampers this process, then a particular niche strategy is required. The second layer of factors (left part of Figure 2), referred to as influencing factors, contains contextual factors that explain why problems in the core system may emerge. Two of these influencing factors relate to knowledge, knowledge of the technology and knowledge of the application. One factor represents the natural resources and labour. Two factors refer to the socio-cultural aspects and the macro-economic aspects that drive or hamper the core system. Finally, accidents and unexpected events are added to the model.

The goal of the model is to assess the market using the factors and then choose a niche strategy that fits the market situation. Our line of reasoning is that the choice for specific niche strategies 
requires a combination of factors. If one of the core factors is missing, it is still not clear which specific niche strategy should be adopted. For example, a lack of customers that are able and willing to adopt the product can be the result of different causes, each of which would call for another niche strategy. Negative economic conditions among potential customers (a lack of spending power) or a lack of (technological) knowledge among potential customers regarding the benefits of the product, could both block large-scale diffusion. However, these causes require completely different niche strategies. The first cause (negative economic conditions) would require a niche strategy aiming at a small top segment of customers (in terms of spending power) or conversely would require a very simple and cheap version of the product that is affordable for more potential customers. In contrast, the second cause (a lack of knowledge among customers) would require a niche strategy focusing on the use of the product in education (to teach potential customers how to use the product) or focusing on a specific segment of knowledgeable users (e.g., in science). We conclude that to assess which niche strategy is appropriate, knowledge is required of the core factors and the influencing factors.

\section{Different market situations and appropriate niche strategies}

The factors on the left side of Figure 2, comprising influencing factors, and those on the right side of Figure 2, comprising the core factors, together determine a particular market situation. In theory, 6 × $6=36$ combinations are possible, each representing a different market situation. However, in practice, not all combinations are relevant as certain influencing factors do not affect certain core factors. For each relevant combination of factors we assess potential barriers and identify which niche strategies can circumvent the barriers.

For example, in several historical cases a lack of knowledge blocked large scale diffusion. Just after the invention of the jet engine in the late 1930s [Constant, 1980] [Jewkes, Sawers \& Stillerman, 1961] [Whittle, 1953] the principle of the engine was demonstrated but a lack of knowledge regarding material technology blocked the large-scale application of the machine. At that time, no materials were available that could withstand the temperatures and pressure inside the jet-engine. Several other cases, such as Videotelephony or Telegraphy at the time of their invention, were confronted with similar difficulties relating to a lack of knowledge [du Boff, 1984] [Ortt, 1998] [Huurdeman, 2003]. In this particular market situation we find one dominant niche strategy, referred to as the "Demo, experiment and develop" niche strategy.

In total we find ten different niche strategies that cover all 36 market situations that we can distinguish. These ten strategies are described in Table 2. The first column in this table shows the names that we give to the ten generic niche strategies, the second column describes the different market situations in which the strategy is applicable, the third column describes the strategy in more detail. The last column mentions some of the historical cases that inspired us to identify the particular niche strategy and a selection of references used to study these cases. Due to space limitations, descriptions of the historical cases are kept to a minimum.

\begin{tabular}{|l|l|l|l|}
\hline $\begin{array}{l}\text { Generic } \\
\text { niche } \\
\text { strategies }\end{array}$ & $\begin{array}{l}\text { Market situation in which they } \\
\text { can be adopted to introduce a } \\
\text { high-tech product or system }\end{array}$ & $\begin{array}{l}\text { Description of the niche } \\
\text { strategy }\end{array}$ & Cases and references \\
\hline
\end{tabular}




\section{4-26 June 2013, the Hague}

\begin{tabular}{|c|c|c|c|}
\hline $\begin{array}{l}\text { Generic } \\
\text { niche } \\
\text { strategies }\end{array}$ & $\begin{array}{l}\text { Market situation in which they } \\
\text { can be adopted to introduce a } \\
\text { high-tech product or system }\end{array}$ & $\begin{array}{l}\text { Description of the niche } \\
\text { strategy }\end{array}$ & Cases and references \\
\hline $\begin{array}{l}1 \text { Demo, } \\
\text { experiment } \\
\text { and } \\
\text { develop } \\
\text { niche } \\
\text { strategy }\end{array}$ & $\begin{array}{l}\text { Knowledge of the technology is } \\
\text { lacking and that affects the } \\
\text { availability of the product itself } \\
\text { because the functionality is not } \\
\text { provided with sufficient quality. }\end{array}$ & $\begin{array}{l}\text { A niche strategy can be } \\
\text { adopted to demonstrate the } \\
\text { product in public in a } \\
\text { controlled way so the limited } \\
\text { quality of performance is not } \\
\text { a problem. As part of the } \\
\text { strategy experimenting with } \\
\text { the product is important to } \\
\text { develop the product further, } \\
\text { for example in a research } \\
\text { environment. }\end{array}$ & $\begin{array}{l}\text { Telegraphy was } \\
\text { demonstrated in multiple } \\
\text { cities before it was put into } \\
\text { use [Dordick, 1990] } \\
\text { [Huurdeman, 2003] } \\
\text { [Winston, 1998]. } \\
\text { Video telephony was } \\
\text { demonstrated on multiple } \\
\text { world exhibitions before } \\
\text { marketable products } \\
\text { emerged in the 1960s [Baird, } \\
\text { 1971] [Ortt, 1998]. }\end{array}$ \\
\hline $\begin{array}{l}2 \text { Top } \\
\text { niche } \\
\text { strategy }\end{array}$ & $\begin{array}{l}\text { Knowledge of the technology is } \\
\text { lacking and that affects the } \\
\text { availability of the product for a } \\
\text { reasonable price. } \\
\text { Knowledge of the technology is } \\
\text { lacking and that affects the } \\
\text { production system with which } \\
\text { controlled production of products } \\
\text { with a constant and good enough } \\
\text { quality and reasonable price is } \\
\text { possible. } \\
\text { Resources for the product or the } \\
\text { production are lacking or very } \\
\text { expensive and that affects the } \\
\text { product's price. }\end{array}$ & $\begin{array}{l}\text { A niche strategy can be } \\
\text { adopted where hand-made } \\
\text { products can be made to } \\
\text { order, in small numbers, for } \\
\text { a specific top-end niche of } \\
\text { the market. } \\
\text { A skimming strategy can be } \\
\text { adopted in which the top } \\
\text { niche of customers is } \\
\text { supplied first with a special } \\
\text { product. }\end{array}$ & $\begin{array}{l}\text { The first cars were made-to- } \\
\text { order and crafted by hand } \\
\text { for a top-niche of the market } \\
\text { [Eckermann, 2001] } \\
\text { [Setright, 2004]. } \\
\text { The strong fiber Dyneema } \\
\text { was hand-made and used in } \\
\text { a special niche before large- } \\
\text { scale production was } \\
\text { possible [Hongo \& Phillips, } \\
\text { 1997] [Mulder, 1992]. }\end{array}$ \\
\hline $\begin{array}{l}3 \\
\text { Subsidized } \\
\text { niche } \\
\text { strategy }\end{array}$ & $\begin{array}{l}\text { Knowledge of the technology is } \\
\text { lacking and that affects the } \\
\text { availability of the product or the } \\
\text { production system and that in turn } \\
\text { affects the availability of the } \\
\text { product for a reasonable price. } \\
\text { Resources for the product or the } \\
\text { production are lacking or very } \\
\text { expensive and that affects the } \\
\text { product's price. }\end{array}$ & $\begin{array}{l}\text { A niche strategy can be } \\
\text { adopted where the product is } \\
\text { subsidized if the use of the } \\
\text { product by a particular } \\
\text { segment of users is } \\
\text { considered as societally } \\
\text { relevant or important. }\end{array}$ & $\begin{array}{l}\text { Video telephony for deaf } \\
\text { people was funded by EU } \\
\text { budgets [Ortt, 1998] } \\
\text { [Dickson \& Bowers, 1974]. } \\
\text { New clean energy } \\
\text { technologies are subsidized } \\
\text { [Caniëls \& Romijn, 2008] } \\
\text { [Kemp et al., 1998]. }\end{array}$ \\
\hline
\end{tabular}




\section{4-26 June 2013, the Hague}

\begin{tabular}{|c|c|c|c|}
\hline $\begin{array}{l}\text { Generic } \\
\text { niche } \\
\text { strategies }\end{array}$ & $\begin{array}{l}\text { Market situation in which they } \\
\text { can be adopted to introduce a } \\
\text { high-tech product or system }\end{array}$ & $\begin{array}{l}\text { Description of the niche } \\
\text { strategy }\end{array}$ & Cases and references \\
\hline $\begin{array}{l}4 \text { Redesign } \\
\text { niche } \\
\text { strategy }\end{array}$ & $\begin{array}{l}\text { Knowledge of the technology is } \\
\text { lacking and that affects the } \\
\text { availability of the product or the } \\
\text { production system and that in turn } \\
\text { affects the availability of the } \\
\text { product for a reasonable price. } \\
\text { Resources for the product or the } \\
\text { production.are lacking or very } \\
\text { expensive and that affects the } \\
\text { product's price. } \\
\text { Knowledge of the application of } \\
\text { the product is missing or socio } \\
\text { cultural aspects affect the } \\
\text { availability of appropriate } \\
\text { institutional aspects (laws, rules } \\
\text { and standards) and thereby } \\
\text { hamper diffusion. } \\
\text { Socio-cultural aspects affect the } \\
\text { availability of suppliers or } \\
\text { customers. }\end{array}$ & $\begin{array}{l}\text { A niche strategy can be } \\
\text { adopted where the product is } \\
\text { introduced in a simpler } \\
\text { version that can be produced } \\
\text { with the existing knowledge, } \\
\text { less use of resources and } \\
\text { therefore for a lower price } \\
\text { A niche strategy can be to } \\
\text { explore an application where } \\
\text { institutional aspects are } \\
\text { more favorable. Mostly } \\
\text { leads to redesign. } \\
\text { A niche strategy can be to } \\
\text { explore an application where } \\
\text { suppliers or customers have } \\
\text { no resistance to produce and } \\
\text { use it. Mostly leads to } \\
\text { redesign. }\end{array}$ & $\begin{array}{l}\text { Furniture design after WW2 } \\
\text { was adapted because } \\
\text { resources such as steel and } \\
\text { wood were scarce and } \\
\text { needed to rebuild countries. } \\
\text { The first personal computers } \\
\text { were apart from the first } \\
\text { professional applications } \\
\text { used as kind of typing } \\
\text { machine rather than using } \\
\text { their full potential [Windrum } \\
\& \text { Birchenhall, 1998]. } \\
\text { The contraceptive pill was } \\
\text { introduced for skin } \\
\text { irregularity because approval } \\
\text { as a contraceptive was } \\
\text { controversial [Junod \& } \\
\text { Marks, 2002]. }\end{array}$ \\
\hline $\begin{array}{l}5 \\
\text { Dedicated } \\
\text { system or } \\
\text { stand- } \\
\text { alone niche } \\
\text { strategy }\end{array}$ & $\begin{array}{l}\text { Knowledge of the technology is } \\
\text { lacking and that affects the } \\
\text { availability of complementary } \\
\text { products and services. }\end{array}$ & $\begin{array}{l}\text { A niche strategy can be } \\
\text { adopted where the product is } \\
\text { used in stand-alone mode or } \\
\text { a dedicated system of } \\
\text { complementary products and } \\
\text { services is designed (e.g., a } \\
\text { local network when an } \\
\text { infrastructure is not } \\
\text { available on a wider scale). }\end{array}$ & $\begin{array}{l}\text { Telephony was first used to } \\
\text { contact the telegraph office, } \\
\text { as a means for intra- } \\
\text { company communication, } \\
\text { and as a dedicated burglar } \\
\text { alarm when the telephony } \\
\text { infrastructure was not yet } \\
\text { available [Huurdeman, } \\
\text { 2003] [Dordick, 1990]. }\end{array}$ \\
\hline $\begin{array}{l}6 \text { Hybridi- } \\
\text { zation or } \\
\text { adaptor } \\
\text { niche } \\
\text { strategy }\end{array}$ & $\begin{array}{l}\text { Knowledge of the technology is } \\
\text { lacking and that affects the } \\
\text { availability of complementary } \\
\text { products and services. } \\
\text { Resources are lacking and that } \\
\text { affects the availability of } \\
\text { complementary products and } \\
\text { services. }\end{array}$ & $\begin{array}{l}\text { A niche strategy can be } \\
\text { adopted by which the new } \\
\text { product is used in } \\
\text { combination with the old } \\
\text { product and thereby all } \\
\text { existing complementary } \\
\text { products and services can be } \\
\text { re-used. Or an } \\
\text { adaptor/convertor is } \\
\text { provided to make the } \\
\text { product compatible with } \\
\text { existing complementary } \\
\text { products and services. }\end{array}$ & $\begin{array}{l}\text { Hybrid car is a way to create } \\
\text { fuel efficient cars when the } \\
\text { infrastructure to use fully } \\
\text { electric cars is not yet } \\
\text { available [Jefferson \& } \\
\text { Barnard, 2002] [Wakefield, } \\
\text { 1998]. }\end{array}$ \\
\hline $\begin{array}{l}7 \text { Educate } \\
\text { niche } \\
\text { strategy }\end{array}$ & $\begin{array}{l}\text { Knowledge of the technology is } \\
\text { lacking and that affects the } \\
\text { availability of suppliers or } \\
\text { customers }\end{array}$ & $\begin{array}{l}\text { A niche strategy can be } \\
\text { adopted aimed at } \\
\text { transferring the knowledge } \\
\text { to suppliers. } \\
\text { An educate and experiment } \\
\text { (pilot) niche strategy can be } \\
\text { adopted aimed at increasing } \\
\text { customer knowledge. }\end{array}$ & $\begin{array}{l}\text { Bell labs organized } \\
\text { conferences to transfer } \\
\text { knowledge regarding } \\
\text { semiconductors and } \\
\text { transistor technology to } \\
\text { manufacturers such as } \\
\text { Raytheon. Bell also } \\
\text { stimulated universities to } \\
\text { develop this knowledge } \\
\text { [Brinkman et al, 1997]. }\end{array}$ \\
\hline
\end{tabular}




\section{4-26 June 2013, the Hague}

\begin{tabular}{|c|c|c|c|}
\hline $\begin{array}{l}\text { Generic } \\
\text { niche } \\
\text { strategies }\end{array}$ & $\begin{array}{l}\text { Market situation in which they } \\
\text { can be adopted to introduce a } \\
\text { high-tech product or system }\end{array}$ & $\begin{array}{l}\text { Description of the niche } \\
\text { strategy }\end{array}$ & Cases and references \\
\hline $\begin{array}{l}8 \text { Geograp- } \\
\text { hic niche } \\
\text { strategy }\end{array}$ & $\begin{array}{l}\text { Knowledge of the technology or } \\
\text { its application is lacking and that } \\
\text { affect the availability of } \\
\text { appropriate institutional aspects } \\
\text { (laws, rules and standards) } \\
\text { Resources are lacking affecting } \\
\text { the availability of the product or } \\
\text { complementary products and } \\
\text { services. } \\
\text { Socio-cultural aspects or macro- } \\
\text { economic aspects affect the } \\
\text { availability of suppliers, } \\
\text { customers and appropriate } \\
\text { institutional aspects. } \\
\text { Accidents and unexpected events } \\
\text { affect the availability appropriate } \\
\text { institutional aspects. }\end{array}$ & $\begin{array}{l}\text { A niche strategy can be } \\
\text { adopted where institutions } \\
\text { (laws and rules) are } \\
\text { relatively easy to arrange or } \\
\text { are less strict. } \\
\text { A niche strategy can be } \\
\text { adopted in another } \\
\text { geographic area where } \\
\text { resources, suppliers or } \\
\text { customers are available. } \\
\text { A niche strategy can be } \\
\text { adopted in another } \\
\text { geographic area where } \\
\text { suppliers are available and } \\
\text { not hampered by these } \\
\text { unexpected events or } \\
\text { accidents. }\end{array}$ & $\begin{array}{l}\text { After some terrible accidents } \\
\text { Nobel was forced to move } \\
\text { the production of Dynamite } \\
\text { to the UK, that also } \\
\text { stimulated the creation of a } \\
\text { new market segment } \\
\text { [Brown, 1998]. }\end{array}$ \\
\hline $\begin{array}{l}9 \text { Lead } \\
\text { user niche } \\
\text { strategy }\end{array}$ & $\begin{array}{l}\text { Knowledge of the application of } \\
\text { the product is missing and that } \\
\text { affects a clear view on customer } \\
\text { applications, specific product } \\
\text { requirements and customer } \\
\text { segments by suppliers. } \\
\text { Socio-cultural aspects, Macro- } \\
\text { Economic aspects or accidents } \\
\text { and unexpected events affect the } \\
\text { availability of suppliers or } \\
\text { customers. }\end{array}$ & $\begin{array}{l}\text { A niche strategy can be } \\
\text { adopted finding innovators } \\
\text { or lead users. These lead } \\
\text { users can co-develop the } \\
\text { product and innovators are } \\
\text { willing to experiment with } \\
\text { the product. }\end{array}$ & $\begin{array}{l}\text { Sport equipment developed } \\
\text { by top sporters themselves } \\
\text { [Herstatt, \& Von Hippel, } \\
\text { 1997]. }\end{array}$ \\
\hline $\begin{array}{l}10 \text { Explore } \\
\text { multiple } \\
\text { markets } \\
\text { niche } \\
\text { strategy }\end{array}$ & $\begin{array}{l}\text { Knowledge of the application of } \\
\text { the product is missing and that } \\
\text { affects the availability of a clear } \\
\text { view on applications, usage } \\
\text { patterns and product benefits by } \\
\text { customers. }\end{array}$ & $\begin{array}{l}\text { A niche strategy can be } \\
\text { adopted in which multiple } \\
\text { customer applications can be } \\
\text { explored. Visibility of the } \\
\text { first applications might } \\
\text { stimulate explorative use in } \\
\text { new applications. }\end{array}$ & $\begin{array}{l}\text { At first it was unclear in } \\
\text { what type of applications } \\
\text { memory metal could be used } \\
\text { [Kauffman \& Mayo, 1996] } \\
\text { [Kumar \& Lagoudas, 2008]. }\end{array}$ \\
\hline
\end{tabular}

Table 2: Ten different niche strategies

\section{Conclusions, discussion and future research}

In this article we pose three research questions: (1) Why are niche strategies important to commercialize new high-tech products? (2) What are specific niche strategies to commercialize new high-tech products? (3) When are these strategies applicable?

Niche strategies are important to commercialize new high-tech products because in many cases large-scale diffusion is simply impossible just after the first market introduction of the product. Earlier work showed that about $80 \%$ of the new high-tech products are introduced in niches prior to large-scale diffusion [Ortt, Trevino Barbosa \& Meijer, 2012]. In this article we describe the factors that hamper large-scale diffusion and thereby cause the emergence of niche applications. Different innovation system models and the outcomes from earlier work are combined to arrive 
at twelve factors that represent important conditions for large-scale diffusion. These factors are divided in two groups. The first group of six factors represents the core technological and market system and includes the new high-tech product itself, the required production system, complementary products and services, suppliers (network of organizations), customers and institutional aspects (laws, rules and standards). The remaining six factors comprise contextual factors that explain incompleteness of the core system. These factors are knowledge of the technology, natural resources and labour, knowledge of the application, socio-cultural aspects, macro-economic aspects and accidents or events.

We combine the core system and the contextual factors to create thirty-six possible market situations requiring niche strategies. Each of these market situations refers to a particular factor in the market environment that affects a particular factor in the core market system and thereby prevents large-scale diffusion. For each market situation multiple historical cases were identified and we assess the niche strategies employed in these cases. We find ten basic niche strategies, most of which are applicable in multiple situations.

We contribute in three ways to the literature and the practice of commercializing new high-tech products. Firstly, we form a simple model comprising twelve actors, factors and functions that should be in place before large-scale diffusion of new high-tech products is possible. This model combines ideas from different innovation system models with empirical findings regarding factors that delay or hamper large-scale diffusion. Secondly, we show how the twelve factor model allows managers, to assess the specific market situation and select one or more niche strategies. Thirdly, we identify ten niche strategies, most of which are applicable in different market situations.

A niche strategy is just one option

It is important to note that after the invention of a new technological principle and after the development of a new high-tech product on the basis of that invention, managers have several strategic options. In general, they can decide to introduce the product or not. In the case managers decide to introduce, they can choose between a mass market introduction and a niche market introduction. A mass market introduction means that a company aims at industrial production and large-scale diffusion soon after the introduction. Earlier work showed that in $20 \%$ of the historical cases of new high-tech products, this is a viable strategy [Ortt, Trevino Barbosa \& Meijer, 2012]. This study also indicates for which market conditions such a strategy is a viable option. If all the core technological and market factors are in place and do not hamper large-scale diffusion, and if none of the contextual factors could block this large-scale diffusion, large-scale introduction is a possibility. In that case this strategy allows a company to quickly lower production costs by attaining economies of scale and that, in turn, will strengthen its competitive position. If a mass market introduction is not possible then a niche strategy can be implemented. Niches strategies form a category of strategies that is important in about $80 \%$ of the cases of new high-tech products that we investigated. We identify ten different niche strategies and indicate in which situation a specific niche strategy is a viable option.

The effect of a niche strategy: circumvent barriers or create a new market?

Niche strategies can be seen as a way to circumvent a barrier that is preventing large-scale diffusion. A geographic niche strategy, for example, circumvents a particular market where the conditions block large-scale diffusion. However, a "demo, experiment and develop niche strategy" tries to take away a barrier, for example by developing the technology required for the product, its production and the complementary products and services. Some of the niche strategies that we identified are a combination of circumventing and creating. An example is a "Top niche strategy" that is adopted in case the price of the product is too high for a mass market introduction. The top niche strategy allows a company to learn by supplying the product to a top niche and thereby slowly increase production rates, reducing the price and creating a larger 


\section{4-26 June 2013, the Hague}

market. Further research is required to better understand how the ten different niche strategies can be used to create new markets.

\section{References}

Abernathy, W.J., Utterback, J.M. (1978) Patterns of Industrial Innovation. Technology Review, No June/July, p. 41-47.

Baird, J.A. (1971) Foreword. The Bell System Technical Journal, Vol 2, p. 219-220.

Bergek, A., Jacobsson, S., Carlsson, B., Lindmark, S., Rickne, A. (2008) Analyzing the functional dynamics of technological innovation systems: A scheme of analysis. Research Policy, Vol 37, No 3, p. 407-429.

Brinkman, W. F., Haggan, D.E., Troutman, W.W. (1997) A History of the Invention of the Transistor and Where It Will Lead Us. IEEE Journal of Solid-State Circuits, Vol 32, No 12 (December), p. 1858-1865.

Brown, G.I. (1998) The Big Bang; History of Explosives. Sutton Publishing Limited, Stroud UK

Caniëls, M.C.J., Romijn, H.A. (2008) Strategic niche management: towards a policy tool for sustainable development. Technology Analysis \& Strategic Management, Vol 20, No 2, p. 245-266.

Constant II, E.W. (1980) The Origins of the Turbojet Revolution. Baltimore, The Johns Hopkins University Press.

Dalgic, T., Leeuw, M. (1994) Niche Marketing Revisited: Concept, Applications and Some European Cases. European Journal of Marketing, Vol 28, No 4, p. 39 - 55.

DeBresson, C. (1995) Predicting the most likely diffusion sequence of a new technology through the economy: The case of superconductivity. Research Policy, Vol 24, No 5, p. 685-705.

Debruyne, M., Moenaert, R., Griffin, A., Hart, S., Hultink, E.J., and Robben, H. (2002) The impact of new product launch strategies on competitive reaction in industrial markets. Journal of Product Innovation Management, Vol 19, No 2, p. 159-170.

Dickson, E.M., Bowers, R. (1974) The Video Telephone; Impact of a New Era in Telecommunications. New York, Praeger Publishers.

Dordick, H.S. (1990) The origins of universal service; History as a determinant of telecommunications policy. Telecommunications Policy, No June, p. 223-231.

du Boff, R.B. (1984) The Telegraph in Nineteenth-Century America: Technology and Monopoly. Comparative Studies in Society and History, Vol 26, No 4 (October), p. 571-586.

Eckermann, E. (2001) World history of the automobile. Warrendale (US), Society of automobile engineers.

Edquist, C. (2011) Design of innovation policy through diagnostic analysis: identification of systemic problems (or failures). Industrial and Corporate Change, No 11, p. 1-29.

Geels, F.W. (2004) From sectoral systems of innovation to socio-technical systems: Insights about dynamics and change from sociology and institutional theory. Research Policy, Vol 33, No 6-7, p. 897-920.

Gerlagh, R., Van der Zwaan, B., Hofkes, M.W., Klaassen, G. (2004) Impacts of CO2-Taxes in an Economy with Niche Markets and Learning-by-Doing. Environmental and Resource Economics, Vol 28, p. 367-394.

Herstatt, C., Von Hippel, E. (1997) Developing New Product Concepts via the Lead User Method: A Case Study in a "Low-Tech" Field. In: Tushman, M.L., Anderson, P. (Eds.): Managing Strategic Innovation and Change. Oxford, Oxford University Press, p. 376-384.

Hongu, T., Phillips, G.O. (1997) New Fibers (2nd Edition). Cambridge, Woodhead Publishing Limited.

Hultink, E.J., Griffin, A., Hart, S., Robben, H.S.J. (1997) Industrial New Product Launch Strategies and Product Development Performance. Journal of Product Innovation Management, Vol 14, No 4, p. 243-257.

Huurdeman, A.A. (2003) The Worldwide History of Telecommunications. Hoboken, New Jersey, WileyInterscience.

Jefferson, C. M., Barnard, R.H. (2002) Hybrid vehicle propulsion. Southampton, WIT Press.

Jewkes, J., Sawers, D., Stillerman, R. (1961) The Sources of Invention. London, McMillan \& Co. Ltd.

Junod, S.W., Marks, L. (2002) Woman's Trials: The Approval of the First Oral Contraceptive Pill in the United States and Great Britain. Journal of the History of Medicine, Vol 57, No April, p. 117-160.

Kauffman, G.B., and Mayo, I. (1996) The Story of Nitinol: The Serendipitous Discovery of the Memory Metal and its Applications. The Chemical Educator, Vol 2, No 2, p. 1-21.

Kemp, R., Schot, J., Hoogma, R. (1998) Regime shifts to sustainability through processes of niche formation: The approach of strategic niche management. Technology Analysis \& Strategic Management, Vol 10, No 2, p. 175-198.

Kumar, P.K., Lagoudas, D.C. (2008) Introduction to Shape Memory Alloys. In: Lagoudas, D.C. (Ed.): Shape Memory Alloys; Modeling and Engineering Applications. New York, Springer, p. 1-51.

Lynn, G.S., Morone, J.G., Paulson, A.S. (1996) Marketing and Discontinuous Innovation: The Probe and Learn Process. California Management Review, Vol 38, No 3, p. 8-37.

Malerba, F. (2002) Sectoral systems of innovation and production. Research Policy, Vol 31, No 2, p. $247-264$.

Meldrum, M.J. (1995) Marketing high-tech products: the emerging themes. European Journal of Marketing, Vol 29, No 10 , p. 45-58. 


\section{4-26 June 2013, the Hague}

Moore, G.A. (2002) Crossing the Chasm. Marketing and Selling Disruptive Products to Mainstream Customers. New York, HarperCollins Publishers.

Mulder, K.F. (1992) Choosing the corporate future: technology networks and choice concerning the creation of high performance fiber technology. Groningen (The Netherlands), Rijks Universiteit Groningen.

Ortt, J. R. (1998). Videotelephony in the Consumer Market. Delft (The Netherlands), Delft University of Technology.

Ortt, J.R., Delgoshaie, N. (2008) Why does it take so long before the diffusion of new high-tech products takes off? In: Proceedings of 17th International Conference on Management of Technology, International Association for Management of Technology (IAMOT), Dubai.

Ortt, J.R., Schoormans, J.P.L. (2004) The Pattern of Development and Diffusion of Breakthrough Communication Technologies. European Journal of Innovation Management, Vol 7, No 4, p. 292-302.

Ortt, J. R., Suprapto, M. (2011) The Role of Strategic Niches in Creating Large-scale Applications for High-tech Products. In: Proceedings of 20th International Conference of the International Association for Management of Technology (IAMOT), Miamibeach, Florida.

Ortt, J.R., Shah, C.M., Zegveld, M.A. (2007). Strategies to Commercialize Breakthrough Technologies. In: Proceedings of 16th International Conference of the International Association for Management of Technology (IAMOT), Miamibeach, Florida.

Ortt, J.R., Trevino Barbosa, S.I., Meijer, S.A. (2012) Sequences of niche applications prior to large scale diffusion. In: Hosni, Y., Hung, S.C., Khalil, T. (Eds.): IAMOT 2012 proceedings: Managing TechnologyService Convergences in the Post-Industrialized Society, Taiwan.

Osepchuk, J. M. (1984) A History of Microwave Heating Applications. IEEE Transactions on Microwave Theory and Techniques MTT, Vol 32, No 9 (September), p. 1200-1224.

Osepchuk, J. M. (2009). The History of the Microwave Oven: A Critical Review. In: MTT '09 proceedings. IEEE MTT-S International, MA Microwave Symposium Digest, 2009. Boston, p. 1397-1400.

Parrish, E.D., Cassill, N.L., Oxenham, W. (2006) Niche market strategy for a mature marketplace. Marketing Intelligence \& Planning, Vol 24, No 7, p. 694-707.

Rogers, E.M. (2003) Diffusion of Innovations. New York, The Free Press.

Rosenberg (1982) Inside the Black Box: Technology and Economics. Cambridge, Cambridge University Press.

Setright, L.J.K. (2004) Drive on! A social history of the motor car. London, Granta Books.

Shani, D., Chalasani, S. (1993) Exploiting Niches Using Relationship Marketing. Journal of Business \& Industrial Marketing, Vol 8, No 4, p. 58 - 66.

Tushman, M.L., Anderson, P. (1986) Technological Discontinuities and Organizational Environments. Administrative Science Quarterly, Vol 31, No 3, p. 439-465.

Tushman, M.L., and Rosenkopf, L. (1992) Organizational Determinants of Technological Change. Towards a Sociology of Technological Evolution. Research in Organization Behavior, Vol 14, p. 311-347.

Tushman, M. L., Anderson, P.C., and O'Reilly, C. (1997). Technology Cycles, Innovation Streams, and Ambidextrous Organizations: Organization Renewal Through Innovation Streams and Strategic Change. Managing Strategic Innovation and Change. M. L. Tushman, and Anderson, P.C. Oxford, Oxford University Press: 3-23.

Utterback, J. M., and Abernathy, W.J. (1975). A dynamic model of process and product innovation. Omega, Vol 3, No 6 (December), p. 639-656.

Wakefield, E.H. (1998) History of the Electric Automobile. Warrendale, SAE International.

Whittle, F. (1953) Jet: The story of a pioneer. London, Frederick Muller Ltd.

Windrum, P., Birchenhall, C. (1998) Is Product Life Cycle Theory a Special Case? Dominant Designs and the Emergence of Market Niches Through Coevolutionary-learning. Structural Change and Economic Dynamics, Vol 9, p. 109-134.

Winston, B. (1998) Media Technology and Society; A History: From the Telegraph to the Internet. New York, Routledge. 